\title{
TRADITIONAL AND DIGITAL TECHNIQUES FOR WORKING WITH LEXICAL MATERIAL IN ENGLISH LESSONS
}

\author{
TÉCNICAS TRADICIONAIS E DIGITAIS PARA TRABALHAR COM MATERIAL \\ LÉXICO EM AULAS DE INGLÊS
}

\author{
TÉCNICAS TRADICIONALES Y DIGITALES PARA TRABAJAR CON MATERIAL \\ LÉXICO EN CLASES DE INGLÉS
}

\author{
Rozaliya M. SHAKIRZYANOVA ${ }^{1}$ \\ Gulnara F. GALI ${ }^{2}$ \\ Leona L. GRIGORIEVA ${ }^{3}$ \\ Alsu S. KHAKIMZYANOVA ${ }^{4}$ \\ Roza R. ZAKIROVA ${ }^{5}$
}

\begin{abstract}
The relevance of this study is due to the fact that the lexical skill is an integral part of all types of speech activity, the formation, improvement and development of which is the main task of teaching a foreign language, namely English. The authors focus on the need for good knowledge of vocabulary for the successful development of communicative competence of students in a globalized world. The purpose of this study is to examine the process of forming language competence when teaching a foreign language and to reveal what techniques are better suited for the pre-intermediate and intermediate students based on the research conducted among the students of the first year at Kazan Federal University. Based on the analysis of effective methods for introducing vocabulary in English classes, the authors identified 10 strategies for effective vocabulary learning and compared traditional and digital methods of its introduction and practice. The authors of this article pay special attention to the experience of activating learning new vocabulary in English classes. Examples of lexical exercises that are typical for each stage of working with the vocabulary are suggested. Conclusions based on the survey of 213 students are drawn.
\end{abstract}

KEYWORDS: Communication. Foreign language. Students. Speech. Communicative competence.

RESUMO: A relevância deste estudo se deve ao fato de que a habilidade lexical é parte integrante de todos os tipos de atividade da fala, cuja formação, aprimoramento $e$ desenvolvimento é a principal tarefa do ensino de uma língua estrangeira, nomeadamente o

\footnotetext{
${ }^{1}$ Kazan Federal University (KPFU), Kazan - Russia. Senior lecturer of the Department of Foreign Languages. ORCID: https://orcid.org/0000-0002-3160-9156. E-mail: rozalja79@mail.ru

${ }^{2}$ Kazan Federal University (KPFU), Kazan - Russia. Professor of the Department of Foreign Languages. Candidate of Pedagogic Sciences. ORCID: https://orcid.org/0000-0002-1063-7166. E-mail: gulnaragali@mail.ru

${ }^{3}$ Kazan Federal University (KPFU), Kazan - Russia. Professor of the Department of Foreign Languages. Candidate of Pedagogic Sciences. ORCID: https:/orcid.org/0000-0002-2855-828X. E-mail: leona212@mail.ru

${ }^{4}$ Kazan Federal University (KPFU), Kazan - Russia. Senior lecturer of the Department of Foreign Languages. ORCID: https://orcid.org/0000-0003-0487-3901.E-mail: alsou80@yandex.ru

${ }^{5}$ Kazan Federal University (KPFU), Kazan - Russia. Professor of the Department of Foreign Languages. Candidate of Pedagogic Sciences. ORCID: https://orcid.org/0000-0002-2702-370X. E-mail: sun_roza@list.ru
} 
Inglês. Os autores enfocam a necessidade de um bom conhecimento do vocabulário para o desenvolvimento bem-sucedido da competência comunicativa dos alunos em um mundo globalizado. $O$ objetivo deste estudo é examinar o processo de formação de competências linguísticas no ensino de uma língua estrangeira e revelar quais técnicas são mais adequadas para os alunos pré-intermediários e intermediários com base na pesquisa realizada entre os alunos do primeiro ano da Universidade Federal de Kazan. Com base na análise de métodos eficazes para a introdução do vocabulário nas aulas de inglês, os autores identificaram 10 estratégias para a aprendizagem eficaz do vocabulário e compararam os métodos tradicionais e digitais de sua introdução e prática. Os autores deste artigo prestam atenção especial à experiência de ativar o aprendizado de um novo vocabulário nas aulas de inglês. Exemplos de exercícios lexicais típicos para cada estágio de trabalho com o vocabulário são sugeridos. São tiradas conclusões com base na pesquisa de 213 alunos.

PALAVRAS-CHAVE: Comunicação. Língua estrangeira. Alunos. Discurso. Competência comunicativa.

RESUMEN: La relevancia de este estudio se debe al hecho de que la habilidad léxica es parte integral de todo tipo de actividad del habla, cuya formación, mejora y desarrollo es la tarea principal de la enseñanza de una lengua extranjera, a saber, el inglés. Los autores se centran en la necesidad de un buen conocimiento del vocabulario para el desarrollo exitoso de la competencia comunicativa de los estudiantes en un mundo globalizado. El propósito de este estudio es examinar el proceso de formación de la competencia lingüística al enseñar un idioma extranjero y revelar qué técnicas son más adecuadas para los estudiantes de pre-intermedio e intermedio según la investigación realizada entre los estudiantes de primer año en Kazan Federal. Universidad. Sobre la base del análisis de métodos efectivos para introducir vocabulario en las clases de inglés, los autores identificaron 10 estrategias para el aprendizaje efectivo del vocabulario y compararon los métodos tradicionales y digitales de su introducción y práctica. Los autores de este artículo prestan especial atención a la experiencia de activar el aprendizaje de nuevo vocabulario en las clases de inglés. Se sugieren ejemplos de ejercicios léxicos típicos de cada etapa del trabajo con el vocabulario. Se extraen conclusiones basadas en la encuesta a 213 estudiantes.

PALABRAS CLAVE: Comunicación. Lengua extranjera. Estudiantes. Discurso. Competencia comunicativa.

\section{Introduction}

In modern society, knowledge of foreign languages is becoming increasingly important. It should be noted that the level of formation of communicative competences directly depends on the quality of mastering, including the lexical side of speech activity. Teaching a foreign language is, first of all, teaching the correct understanding and use of its words and vocabulary. The role of vocabulary is very important, because it is the vocabulary that conveys the immediate subject of thought (VALEEV et al., 2019). 
Kato Lomb (1993), a well-known Hungarian interpreter, writer, and one of the first simultaneous interpreters in the world, used to say that "the word is a "brick" in the construction of a building, where the building is the language, and construction is the study". Just as a reliable and strong brick is important for a building, so for a language, the word must be a reliable and understandable form of expression of thought (BAUMANN; WARE, 2007).

In almost every foreign language lesson, we work on expanding our vocabulary, on each specific word on a specific topic. When working with a word, you need a certain algorithm of actions not only on the part of the teacher, but also on the part of students. Visual perception of the word (visibility), sound perception (repetition of the teacher or the speaker), written perception (writing the word in the vocabulary list, preferably in phrases and sentences). Finding a word in the text, using the word in a conditional speech exercise, using the word in communicative communication (CUNNINGHAM, 2000).

Lack of vocabulary is causing a sense of insecurity among students and the reluctance to speak a foreign language. To know a word is to know its forms, meaning, and usage. Speaking about the forms of the word, we mean its sound form, without which it is impossible to correctly understand the word and adequately voice it yourself, as well as the graphic form, without which the word will not be recognized when reading and can not be written. As for meaning, in English, as in any other language, words can have multiple meanings. Successful development of communicative competence is impossible without good knowledge in the field of vocabulary, because it is used to receive and transmit information. In this regard, both in additional classes (clubs) and in foreign language lessons, it is necessary to work on expanding the vocabulary, on each specific word on a specific topic. It is necessary for each of the students to understand that the memorization of words should not be mechanical, that each word should be understood, correctly pronounced, read and written. Only after the word gets a clear semantic, auditory, and graphic image in the student's mind can you start working on memorizing it and fixing it. Therefore, the main stages of working on vocabulary include: I) familiarization with new material (including semantics), II) primary consolidation and III) development of communicative competence based on the studied lexical units (LE) (ABROSIMOVA et al., 2019). 


\section{Methodology}

The object of our research is:

- stages and methods of introducing vocabulary in traditional and digital ways;

- principles of selection of lexical material by the teacher;

- types of exercises for learning new vocabulary;

- strategies for effective vocabulary learning;

- research of the most effective vocabulary introduction and learning methods among the students of Kazan Federal University.

When researching our topic, we used the following methods:

- communicative method of teaching English;

- methods of working with vocabulary;

- role-playing games when introducing lexical material;

- survey among 213 respondents.

The theoretical and methodological basis was the analysis of scientific works of Russian and foreign authors: Valeev et al. (2019), Kuznetsova (2011), Cunningham (2000), Rogova, Rabinovich and Sakharov (2011), Shakirzyanova and Zakirova (2019), Antonacci and O’Callaghan (2019), Buckowiecki (2006), Jackson (2014), Henrichs (2011) and others.

\section{Results and discussion}

Among the range of issues that make up the content of foreign language teaching methods, the problem of lexical selection has one of the leading places. A properly compiled educational vocabulary list is a necessary tool for the teacher, since it focuses on a strictly limited range of vocabulary to be learned. It is necessary to keep in mind that the main goal is ability to use the words, not their knowledge. Therefore, the learner must have the necessary number of words, regardless of what type of speech activity these words are necessary for.

Learning new lexical units involves the certain stages:

1) Representation (semantics) of lexical units

2) Vocabulary automation

3) Improving lexical skills. 
When introducing (semanticizing) vocabulary, the teacher can use different methods and techniques, such as translation or non-translation methods. When choosing methods of working with vocabulary, the teacher should pay attention to the following aspects:

- character of the word;

- level of students;

- stage of training.

The introduction of vocabulary can be carried out in various ways, which can be divided into non-translation and translation methods of introduction (MAY, 2004).

Non-translation methods include:

1) demonstration of objects, actions, pictures, drawings, etc.;

2) when revealing the meanings of the words in a foreign language, you can use: definition, enumeration, synonyms or antonyms, figuring out meaning in context. An important and very valuable means of revealing the meaning of words is the definition. This tool, firstly, most accurately reveals the meaning and, secondly, trains students in understanding speech by ear. However, the interpretation of values is quite difficult for the teacher and implies a high level of knowledge, skills and abilities of students.

Translation methods include:

1) replacing words and phrases with the appropriate version of the native language;

2) translation.

Non-translation methods are used at the primary and secondary level and help make the lesson interesting and mobile. These types of exercises help to develop ability to guess, increase practice in the language, and create basis for memorization. However, non-translation methods require more time than translation ones, and do not always provide accurate understanding. Translation methods are appropriate in the senior level, when it is impossible to explain the word.

Existing digital techniques expand a variety of tools to introduce new vocabulary, help to motivate students. The above mentioned translation and non-translation methods could be applied through power-point presentations, videos, websites. The teacher can use authorial material or already existing content from the Internet. 
Introduction of the word. The word can be introduced independently, and then the student can see the use of the word in the sentence and text (KUZNETSOVA, 2011).

Stages of working with vocabulary:

a) pronunciation of the word;

b) checking the correct pronunciation;

c) correction of detected errors;

d) control of understanding;

e) writing the word or presenting it in a digital way.

Memorizing vocabulary. At this stage, the teacher uses various exercises, such as crosswords, finding words and definitions, filling in the missing letters, making phrases, picking up a word in a sentence. The tasks can be suggested for students in the printed or online format.

Activating vocabulary is the final stage of working with new words. The main way to activate vocabulary is to use it in various exercises, such as dialogues, role-playing games, writing, and projects.

Enriching students' vocabulary is the most important task of a foreign language teacher. There are two goals of vocabulary enrichment:

- quantitative increase of words and qualitative improvement of the existing stock of words;

- learning how to use already known and newly learned words.

Both of these goals must be implemented in the classroom (JACKSON; NARVAEZ, 2013).

How can we ensure that the lesson of enriching speech with new lexical material was effective? First of all, teachers must know the material from which to choose words, they can take those words that are included in live communication, typical for literary colloquial speech. Sometimes the teacher can be guided by intuition. After selecting all the material for oral speech, the teacher must give students the meaning of all lexical units. There are many ways to do this (YATES; CUTHRELL; ROSE, 2011).

Getting ready for the lesson, the teacher makes a short story containing new words (the grammatical material must be known); the content of the story differs from the content of the future text. Sometimes it is paraphrasing, sometimes replacing some details or theme. For 
example, if the text refers to London, you can make a story about our city. When you get to a phrase with new words, you can slow down the pace of the story and highlight the new word with intonation. You can even repeat the phrase and then explain the meaning of the word. Words are fixed in the memory with a number of questions with a given lexical unit.

1. Was London founded XX centuries ago? Yes, it was.

2. When was Mariinsk founded? Mariinsk was founded in 1856.

3. Was Kemerovo founded on the river Tom? Yes, it was.

If we need to fix and explain the meaning of only 3-4 words and if the memory of students is developed, we can do this: students listen to the story, and memorizing is carried out after the end of the story.

For most people speed is a very important factor when they are travelling. They want to reach their destination as quickly as possible. There are now planes that can cross the Atlantic in just over three hours.

Other people prefer comfort to speed. They like to relax during the journey and enjoy themselves as much as possible.

In this text new words are the following:

- To reach.

- Destination.

- $\quad$ Possible.

- $\quad$ Speed.

- To relax.

When you are sure that students understand speech well, you can hold a conversation about a movie, a book you have read, or about events in the country. And new words are introduced in this conversation.

If a word cannot be introduced in a conversation, then the situation is the most convenient way for introduction. In each situation, you must enter one or two words, the meaning of which is revealed in the situation by guess. By changing the situation, working on words will not be so monotonous.

At the initial stage of training, when the vocabulary of students is still poor, it is better to use a phrase and a number of similar sentences containing new words. 
For instance:

A) How do you like to travel?

I like to travel by train.

I like to travel by plane.

I like to travel by ship.

B) Are you busy?

Yes, I am.

Are you sick (tired, ill, free)?

No, I am not.

Considering the small level of vocabulary of students, the teacher uses visuals, which provides invaluable assistance in learning words at the initial stage.

For example: when studying the topic "House and apartment", a classroom with existing objects is used as a visual aid (a room, a window, a door, ceiling, a blackboard, floor, a shelf, a bookcase, a picture, a table, a chair, a lamp).

By naming these items, students can easily remember them and then use them when describing their room, apartment, or home. We should not forget about etymological supports in the Russian language. In other words, these are international words the meaning of which students can easily guess: the ability to see and understand them makes it easy to read and translate (signal, diesel, temperature, reactor, motor, energy, text, practical, director, method, mechanism, effect).

The digital techniques allow the teachers to create digital vocabulary fields where the students can see information from different websites on the given lexical unit or vocabulary group.

Many English words in their original form can refer to different parts of speech. It is only possible to determine which part of speech a word in a sentence belongs to based on its syntactic function and morphological features. This method is very common in the English language.

- Work.

- $\quad$ Struggle.

- Trouble.

- Clear.

- Help. 
- $\quad$ Play.

Most difficulties in translating from English into Russian are caused by words that have different meanings. For example: the word "light" can act as a noun, an adjective and as a verb. You can choose the right word meaning only based on the context, that is, the words surrounding the given word.

1. There is no light in this corridor as there are no windows in it.

2. The room is light and clean.

3. Why did they light that lamp?

Some English words in a sentence are only nouns, but with different meanings that students sometimes find difficult to find.

- $\quad$ Game - igra; dich'.

- $\quad$ Club - klub; dubinka.

- $\quad$ Figure - figura; tsyfra.

- $\quad$ Flat - kvartira; ploskost.

- Crank - krivoship; chudachestvo.

- $\quad$ Match - spichka; sostyazanie.

- $\quad$ Spring - vesna; pruzhina.

It is very important to control the understanding of complex words that are formed by adding two words. Some words students can easily guess their meaning.

- $\quad$ First-class

- Snow-covered

- $\quad$ Reading-room (hall)

- $\quad$ Everywhere

- $\quad$ Voltmeter

- $\quad$ Classroom

- $\quad$ Blackboard

- Letterbox.

At the same time for the question "what is kitchen garden", they don't give an answer. Although, they know the words separately. 
1. kitchen, garden - sad, kitchen garden - ogorod.

2. lady - dama, bird - ptitsa, lady bird - bozhiya korovka.

3. flower - tsvetok, bed - krovat, flower bed - klumba.

4. butter - maslo, fly - mukha, butterfly - babochka.

5. $\quad$ hide - pryatat', seek - iskat', hide-and-seek - igrat' v pryatki.

In English, great difficulties are encountered with the phonetic sound of words. Phonetic structure of English is significantly different from the phonetics of the Russian language. The main differences are determined by the presence of specific sounds from those existing in the native language, characteristic articulation and pronouncing skills, and intonation originality. The peculiarity of vowel pronunciation is their division into long and short ones (HARMON et al., 2009).

Many of these difficulties could be overcome through application of multimedia onlinedictionaries to search for definitions, synonyms, antonyms, collocations, phraseology, phonetic structure of the words.

Many teachers are concerned about whether it is necessary to write down words and when to write them down. Words must be written. The fact is that many students have much better visual memory than auditory memory. It is better to write words in advance on the board without translating them into Russian. Even better, if the word is associated with microtext or phrases that are also written on the board. Not only hearing and producing, but also seeing the word at the right time is the key to success (HILDEN; JONES, 2012). Introducing a word form with the help of digital technology could be used instead of traditional writing down the word on the board. Listening to digital texts can help to automate the acoustic perception of the word.

Let oral anticipation last no longer than the process of semantics. The meaning of the word is revealed, afterwards we write it on the board or introduce through the digital technologies and automate it. We present the story, select new words from it, write them on the board or introduce in another digital way and start the exercises, automation. Automation of a word is its assimilation, it depends on whether the student will memorize the word. There are a lot of exercises for memorizing words. Some of them include creative work (such as making dialogues or making crosswords). 
Types of exercises:

1. Question - answer;

2. To continue the phrases. For example: We like to travel by....

The student continues: by ship, by plane, by train, etc.

3. You can express an idea and encourage students to respond: as for me I get to my work by bus. What about you? I get to the technical school on foot.

4. Ask a friend. How do you like to travel? What is your quickest way of travelling?

5. Make situations with the words: (Ticket, to book, for pleasure, carriage, suitcase, to buy, to carry, money и т. д.)

6. Make dialogues.

7. Fill in the missing words (usually the new ones).

8. Make sentences from words given randomly, but with correct grammar constructions.

9. Make crosswords or underline new words from the mixed letters.

10. Visual aids, especially story paintings, are also a great help.

For example, for the theme "Travel" the teacher can use pictures of modes of transport, tickets, money, bags, suitcases, cities.

One of the important aspects of the training method is repetition. There are two types of repetition: current and final.

The question of the repetition of words related to certain topics requires organization of repetition. The purpose of repetition is to preserve the words in memory, in readiness for their use in oral speech and for understanding them in the process of reading. The most important thing is the current repetition of old material in the process of learning a new vocabulary.

Old material is reproduced in new combinations. For example: verb to book zakazyvat'.

1. We are fond of booking tickets in advance.

2. We would like to book tickets for the train.

Generalized repetition is used to collect material on the topic studied. For example, you are given a task to list everything that you can buy in a department store or what you can take with you on the road. 
The final repetition at the end of the year can be performed if the lexical material is included in the speech activity.

For this form of repetition the following tasks are used: making dialogues, stories, listening to texts in a recording with the explanation its content (BUCKOWIECKI, 2006).

Thus, by studying this material, the authors identified the following strategies for effective vocabulary learning in English classes.

1. The use of semantic fields. Divide an A4 sheet into four rectangles. At the intersection of these lines, write a word or phrase that you want to remember. Sign each rectangle, starting from the top left in a clockwise direction:

- Description: Define the term using your own words.

- Characteristics: Give at least 3 interesting characteristics of the term.

- Synonym: What is it like?

- Antonym: What is it not like?

Students use their vocabulary to fill in rectangles. Supplement them with drawings or diagrams.

This way of memorizing helps students learn new words. If you define new lexical units in your own words, give examples from familiar situations and visual images, then any word will stay in your memory for a long time.

2. Writing new phrases and words using associations. If the words you need to remember are associated with items, ask students to create posters with these words.

3. Guess the meaning of the word. You can use the reading of the new text in class.

4. A tag cloud is a collection of keywords or information selected from an excerpt or chapter that students are going to read. This strategy gives students a chance to associate new words or information with the main idea of the text to read. This helps to retell the main content of the text well.

5. The grouping of words. Provide the group with a list of words for the topic you are studying. Students should group them into different categories (parts of speech, character, clothing, school).

6. Crossword.

7. Words that are used together. You can suggest creating complex nouns: snow + boarding, wind + surfing, mountain + biking. Or connect a verb or adjective with a preposition: listen + to, look + at, agree + with, good + at, interested + in. 
We have assumed that in order to reveal the most effective techniques for introduction and practicing of new vocabulary, it is relevant to conduct a research based on the interview of 213 students of Kazan Federal University, among which were the students of their first year study at the faculty of law. Only the students of B1 and B2 levels of English took part in the survey, since at this level it is essential to improve vocabulary learning to enable them to express their thoughts, understand authentic texts, master their writing, listening skills. Kazan Federal University is one of the oldest (founded in 1804) and largest institutions of higher education in Russia which gained its world-wide fame in various fields such as mathematics, law, oriental studies, physics, medicine and many other and which pays specific attention to adopting digital methods of learning for their home country and international students.

The questionnaire used contained the following questions:

1. Do you experience difficulties in learning knew vocabulary?

2. How many words and phrases will you be able to learn within 1 week $(0-10,10$ 20 , more than 20)?

3. Would you prefer traditional or digital tools for introduction and practice of new vocabulary?

4. What helps you to learn new vocabulary more effectively (choose any 3 ):

- Visualization;

- $\quad$ Creative assignments;

- $\quad$ Drill exercises;

- $\quad$ Learning about etymological characteristics of the words;

- $\quad$ Word formation tasks (finding prefixes, suffixes, etc.);

- $\quad$ Learning synonyms and antonyms of a lexical unit or phrase;

- $\quad$ Perception of a word within a thematic group;

- $\quad$ Suggest your own method if there is any.

The research showed that only 1 out 10 people in this survey experiences difficulties in learning new words and phrases if they consider the phonetic structure of the word difficult (see pie chart 1): Pie chart 1. 


\section{Chart 1}



Source: Prepared by the authors

The majority of respondents (60 per cent) said that the most suitable amount of words and phrases they can learn in a week equals 10-20 lexical units. Only 1 out of 10 students is able to learn more than 20 new words in a week. 3 out of 10 students can learn less than 10 words (see pie chart 2):

\section{Chart 2}

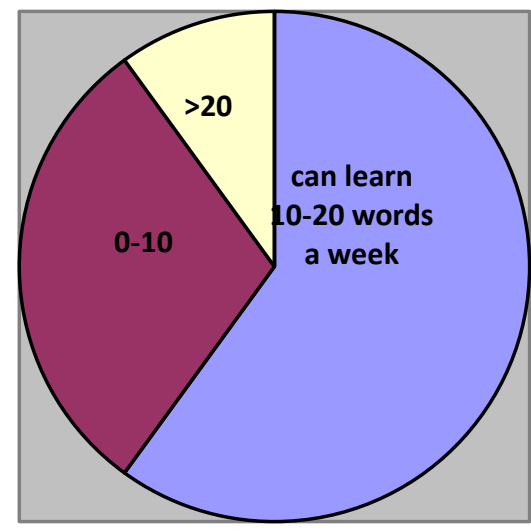

Source: Prepared by the authors

The amount of the students who preferred traditional methods for introduction and practice of vocabulary was equal to those who would rather choose digital tools (see pie chart $3)$ : 


\section{Chart 3}

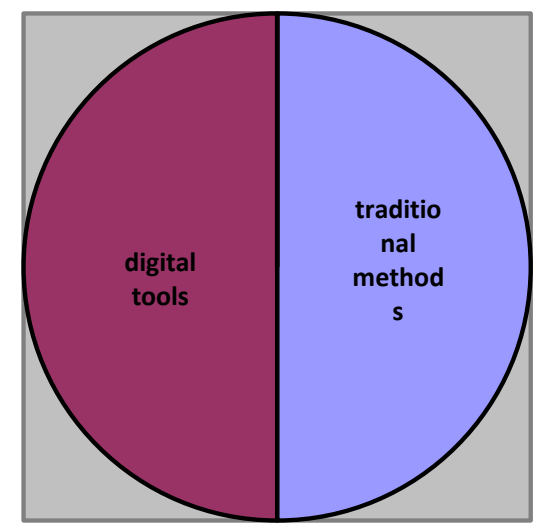

Source: Prepared by the authors

The most effective ways that help to learn new vocabulary are presented in the Frame 1 in accordance with their popularity among the respondents,

\section{Frame 1}

\begin{tabular}{|ll|}
\hline 1. & Visualization \\
\hline 2. & Drilling \\
\hline 3. & Creative assignments \\
\hline 4. & Learning of synonyms and antonyms \\
\hline 5. & Learning etymological characteristics of the word \\
\hline 6. & Perception of the word within thematic group \\
\hline 7. & Word formation tasks \\
\hline
\end{tabular}

Source: Prepared by the authors

We may conclude, that in order to avoid difficulties in learning new words, it is recommended to start with explaining the phonetic structure of the word. The amount of words and phrases to be learnt in a week should be equal between 10 and 20 for B1 and B2 students. The results clearly show that teachers should imply traditional as well as digital methods for introduction and practicing new vocabulary to meet the needs of all students. The three most highly ranked techniques for introduction and practicing of new vocabulary are visualization, drilling, creative assignments. 


\section{Discussion}

The basic reason to make a detailed analysis of issues related to the process of forming language competence is the successful development of communicative competence of students. The research has shown that the problem is considered as one of the most important in teaching a foreign language. Of course, particular attention to enhancing the study of new vocabulary in English lessons is given by many researchers. Various aspects of teaching vocabulary are reflected in the scientific work of researchers: Antonacci and O'Callaghan (2019), Cunningham (2000), Coskie and Davis (2009), Eremeeva (2016), Kent (2006), Kondrateva (2018), May (2004), Rogova, Rabinovich and Sakharov (2011), Solovyova (2012), Khusainova Valeev (2018) and others.

However, analysis of scientific papers on this issue showed us that this problem is not sufficiently considered.

\section{Summary}

In the course of investigating of this problem, the authors came to the following conclusions:

- a properly compiled educational vocabulary list is a necessary tool for the teacher;

- enriching students' vocabulary is the most important task of a foreign language teacher;

- in order to avoid difficulties in learning new words, it is recommended to start with explaining the phonetic structure of the word;

- teachers should imply traditional as well as digital methods for introduction and practicing new vocabulary to meet the needs of all students.

\section{Conclusion}

Thus, the main goal of teaching vocabulary is to develop students' skills as one of the most important components of speaking skills, listening, reading and writing. Knowing the vocabulary, the student will be able to freely use all four types of speech activity, effective work on which contributes to the achievement of the main communicative goal - the formation of foreign language communicative competence. Teaching foreign language vocabulary is one of the most relevant topics in modern methods of teaching English, since it is part of oral 
communication activities and is used in any oral communication that could be implemented through traditional and digital methods.

ACKNOWLEDGEMENTS: The work is performed according to the Russian Government Program of Competitive Growth of Kazan Federal University.

\section{REFERENCES}

ABROSIMOVA, G. A. et al. Blended learning in university education. Humanities \& Social Sciences Reviews, v. 7, n. 6, p. 6-10, 2019.

ANTONACCI, P. A.; O’CALLAGHAN, C. M. Promoting literacy development: researchbased strategies for K-8 learners. California: SAGE Publications, Inc., 2011. 167 p.

BAUMANN, J.; WARE, W. E. Edwards, bumping into spicy, tasty words that catch your tongue: A formative experiment on vocabulary instruction. The Reading Teacher, n. 61, p. 108-122, 2007.

BUCKOWIECKI, E.M. Vocabulary instruction: advice to new teachers. New England Association Journal, v. 2, n. 42, p. 29-40, 2006.

COSKIE, T. L.; DAVIS, K. J. Word wall work: Supporting science talk. Science and Children, v. 46, n. 8, p. 56-58, 2009.

CUNNINGHAM, P. Phonic they use: words for reading and writing. 3. ed. New York: Longman-Addison Wesley, 2000. 232 p.

EREMEEVA, G. R. Dialogization of professional communication between students and lecturers. Journal of Organizational Culture, Communications and Conflict, n. 20, p. 128-134, 2016.

HARMON, J. M. et al. Interactive word walls: more than just reading the writing on walls. Journal of Adolescent \& Adult Literacy, n. 52, p. 389-408, 2009.

HENRICHS, E. L. Interactive word walls and student perceptions of vocabulary. Texas State University, 2011. Available: https://digital.library.txstate.edu/handle/10877/2473. Access: 04 June 2020.

HILDEN, K.; JONES, J. Classroom word walls: is yours a tool or a decoration? Reading Today, v. 29, n. 4, p. 9-11, 2012.

JACKSON, J. K. Interactive, conceptual word walls: Transforming content vocabulary instruction one word at a time. International Research in Education, v. 2, n. 1, p. 37-46, 2014. 
JACKSON, J.; NARVAEZ, R. Interactive word walls: create a tool to increase science vocabulary in five easy steps. Science and Children, v. 51, n. 1, p. 42-49, 2013.

KENT, M. A. The effect of systematic word wall instruction on the literacy achievement of first grade students. UMI No. 30558, 2006. 176 p.

KHUSAINOVA, R. R.; VALEEV, A. A. Technological aspect of the development of university students foreign language activities. Astra Salvensis, n. 6, p. 746-764, 2018.

KONDRATEVA, I.; SABIROVA, D.; PLOTNIKOVA, N. Subjectivity functions in reflexive and intercultural process of linguistic development. Cypriot Journal of Educational Sciences, v. 13, n. 4, p. 529-536, 2018.

KUVSHINOV, V. I. About work with vocabulary in school. Foreign Languages at School, n. 5, p. 20-24, 2015.

KUZNETSOVA, T. M. Stages of work on the word. Foreign Languages at School, n. 5, p. 88-94, 2011.

MAY, B. Will using a classroom word wall help students successfully learn high frequency words? Winona State University Anthology of k-12 language arts action research, ERIC document Reproduction Service, ED 494233. 2004.

ROGOVA, G. V. RABINOVICH, F. M.; SAKHAROV, T. E. Methods of teaching foreign languages in secondary school. Moscow: Education, 2011. 254 p.

SHAKIRZYANOVA, R. M.; ZAKIROVA, R. R. The creativity development of teenagers in leisure time. Humanities \& Social Sciences Reviews, v. 7, n. 6, p. 76-80, 2019.

SOLOVYOVA, E. N. Methods of teaching foreign languages. Basic course of lectures / manual for students and teachers in ped. Universities. Moscow: Education, 2012. 321 p.

VALEEV, A. A. et al. Major areas of foreign language speech activity of university students improvement. Humanities \& Social Sciences Reviews, v. 7, n. 6, p. 967-977, 2019.

YATES, P.; CUTHRELL, K.; ROSE, M. Out of the room and into the hall: making content word walls work. The Clearing House: A Journal of Educational Strategies Issues and Ideas, v. 84, n.1, p. 31-36, 2011. 


\section{How to reference this article}

SHAKIRZYANOVA, R. M.; GALI, G. F.; GRIGORIEVA, L. L.; KHAKIMZYANOVA, A. S.; ZAKIROVA, R. R. Traditional and digital techniques for working with lexical material in english lessons. Rev. EntreLínguas, Araraquara, v. 7, n. esp. 3, e021060, Sep. 2021. e-ISSN: 2447-3529. DOI: https://doi.org/10.29051/el.v7iesp.3.15731

Submitted: 10/01/2021

Required revisions: 20/03/2021

Approved: 23/06/2021

Published: 01/08/2021 